\title{
Pengaruh Job Insecurity Terhadap Turnover Intention
}

\author{
Muhammad Iqbal Nurfauzan ${ }^{1 *}$ dan Ii Halilah ${ }^{2}$ \\ ${ }^{1}$ Jurusan Administrasi Niaga, Politeknik Negeri Bandung, Indonesia \\ ${ }^{2}$ Jurusan Administrasi Niaga, Politeknik Negeri Bandung, Indonesia
}

\begin{abstract}
:
This study aims to determine how the image of job insecurity, turnover intention and influence of job insecurity on turnover intention in PT Sandy Globalindo. The method used in this research is descriptive method, while the data collection techniques is interviewing and distributing questionnaires to 101 respondents who were determined by simple random sampling. Based on the research that has been done, regression equation is $Y=26543+$ 0,398X. The study states that in PT Sandy Globalindo, job insecurity and turnover intention have a positive relationship was at 0.464 and job insecurity influence turnover intention of $21,5 \%$.
\end{abstract}

Keywords: human resources, job insecurity, turnover intention

\section{PENDAHULUAN}

\section{Latar Belakang Penelitian}

Sumber Daya Manusia (SDM) meupakan salah satu faktor yang menjadi keberhasilan perusahaan dalam menjalankan usahanya. SDM adalah faktor utama perusahaan dan mempunyai peranan penting dalam membantu perusahaan mencapai tujuannya. SDM dalam perusahaan harus dikelola dengan sangat baik untuk meningkatkan efektivitas dan efisiensi organisasi. Menurut Daryanto \& Abdullah (2013: 2) manajemen adalah cara manajer (orangnya) mengatur, membimbing, dan memimpin semua orang yang menjadi pembantunya agar usaha yang sedang dilakukan dapat mencapai tujuan yang telah ditetapkan sebelumnya. Usman (2010:5) berpendapat bahwa manajemen adalah perencanaan, pengorganisasian, pengarahan, dan pengendalian sumber daya organisasi untuk mencapai tujuan secara efektif dan efisien.

Kondisi dan perilaku karyawan sangat menentukan kinerja suatu organisasi.

*Email korespondensi:

Muhammad Iqbal Nurfauzan

muhammadiqbalnurfauzan@gmail.com
Intensi keluar atau keinginan berpindah (turnover intention) merupakan salah satu masalah yang dialami oleh perusahaan. Dalam dunia kerja, terdapat hubungan antara pekerjaaan dan kondisi mental seseorang. Hubungan tersebut dapat dilihat pada gambar 1.

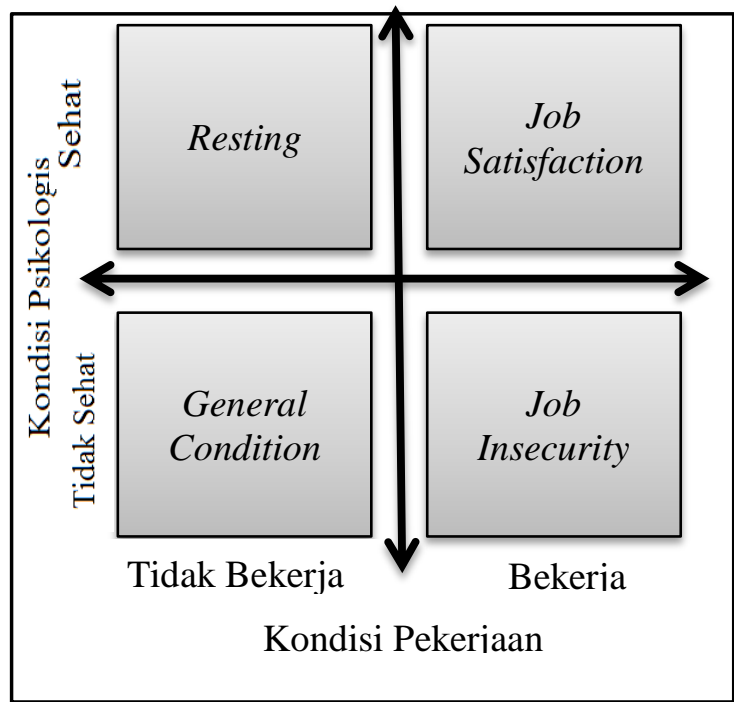

Gambar 1. Hubungan antara Pekerjaan dan Kondisi Mental Seseorang (Burchell dalam Nopiando, 2012:4)

Gambar 1 merupakan matriks yang menunjukkan hubungan antara status pekerjaan seseorang beserta kondisi 
mentalnya. Ada 4 kondisi pekerjaan dan mental seseorang, yaitu general conditions, resting, job insecurity, dan job satisfaction.

General conditions adalah kondisi pertama yang umum terjadi di mana seseorang yang tidak bekerja dan mengalami gangguan psikologis. Keuntungan ekonomis dan psikologis adalah alasan seseorang untuk bekerja. Kompensasi yang didapatkan dari perusahaan dapat memenuhi segala kebutuhan seseorang. Seseorang akan mendapatkan kepuasan dan kebanggaan tersendiri dengan bekerja, karena dengan bekerja seseorang dapat mengimplementasikan pengetahuannya. Jika seseorang tidak bekerja, bukan hanya kesulitan ekonomi yang didapat, tetapi juga terganggu kondisi psikologisnya.

Resting adalah kondisi kedua di mana seseorang yang tidak bekerja dan tidak mengalami gangguan psikologis. Kondisi ini berbeda dengan kondisi yang pertama. Perbedaannya adalah, kondisi ini ditemukan pada orang yang sebelumnya bekerja, tetapi pekerjaan tersebut tidak mendatangkan kepuasan yang bisa saja disebabkan oleh rasa letih fisik dan atau mentalnya. Orang-orang ini biasanya adalah mereka yang telah memasuki masa pensiun atau yang sudah melewati usia produktif.

Job insecurity adalah kondisi ketiga dimana seseorang yang bekerja tetapi mengalami gangguan psikologis. Kondisi ini dipengaruhi oleh faktor lain, seperti lingkungan pekerjaan dan kepastian keberlanjutan pekerjannya dalam organisasi. Tidak jarang hal seperti ini diiringi dengan kondisi bahwa seseorang tersebut memiliki kecocokkan dan keterikatan yang tinggi dengan organisasi dimana mereka bekerja. Di satu sisi mereka ingin terus eksis di dalam organisasi tempat mereka bekerja, tetapi di sisi lain mereka merasa bahwa posisinya (pekerjaan dan keberadaannya dalam organisasi) terancam.

Job Satisfaction adalah kondisi keempat dimana seseorang yang bekerja dan tidak mengalami gangguan psikologis. Ini adalah kondisi yang baik dimana seseorang memiliki pekerjaan dan pekerjaan tersebut mendatangkan kepuasan kerja (job satisfaction) padanya. Dalam kondisi ini, mereka telah memilih pekerjaan mereka sesuai dengan kompetensi (competency) dan motivasi (willingness) mereka.

Karyawan yang memiliki sikap positif terhadap pekerjaan akan lebih rendah absensi dan pengunduran dirinya. Perusahaan tidak menginginkan adanya karyawan terampil keluar dari perusahaan. Dampak negatif seperti ketidakstabilan dan ketidakpastian akan muncul karena perusahaan kehilangan karyawan yang sudah terampil dan perlu melatih kembali karyawan baru untuk menggantikan peran karyawan yang keluar. Selain itu, banyaknya karyawan pada suatu organisasi yang keluar mengakibatkan tingginya biaya perekrutan karyawan baru, proses seleksi, dan pelatihan yang harus ditanggung organisasi. Hal tersebut sejalan dengan apa yang dimaksud oleh Kadiman dan Indriana (2012 : 65) bahwa intensitas turnover yang tinggi dapat menyebabkan perusaahan tidak dapat memperoleh manfaat dan keuntungan dari program peningkatan kinerja karyawan karena mengeluarkan biaya yang lebih besar pada program rekrutmen karyawan baru.

Ada banyak faktor yang membuat individu memiliki keinginan untuk berpindah. Menurut Handoyo (dalam Yanita, 2012: 2) faktor-faktor tersebut diantaranya adalah lingkungan kerja, komitmen organisasional dari karyawan, kepercayaan terhadap organisasi, dan ketidakamanan kerja (job insecurity). Menurut Mobley (dalam Hanafiah, 2014: 306) ada banyak faktor yang membuat individu memiliki turnover intention. Faktor-faktor tersebut diantaranya adalah kepuasan kerja, komitmen organisasi dari karyawan, kepercayaan terhadap organisasi, dan job insecurity.

Smithson \& Lewis (dalam Wardani, 2014: 30) mengartikan job insecurity sebagai kondisi psikologis seseorang karyawan yang menunjukkan rasa bingung atau merasa tidak aman dikarenakan kondisi lingkungan yang berubah-ubah (perceived impermanance). 
Turnover intention merupakan masalah umum yang sering dihadapi oleh perusahaan. Turnover intention cenderung didefinisikan secara sukarela menurut pilihannya. Hal ini dipertegas Tett dan Meyer (dalam Waspodo, 2013: 101) bahwa turnover intention mengacu pada keinginan yang secara sadar dan disengaja untuk meninggalkan organisasi. Untuk mengetahui keadaan mengenai job insecurity dan turnover intention, maka dilakukan studi pendahuluan berupa wawancara informal kepada manager produksi PT Sandy Globalindo mengenai jumlah karyawan yang keluar terhitung dari tahun 2011-2015. Berikut data jumlah karyawan yang keluar disajikan dalam tabel 1.

Tabel 1 Jumlah Karyawan Keluar Periode 2011-2015

\begin{tabular}{|c|c|c|c|}
\hline \multirow[b]{2}{*}{ No } & \multirow[b]{2}{*}{ Keterangan } & \multicolumn{2}{|c|}{ Jawaban } \\
\hline & & $\begin{array}{c}\text { Jum } \\
\text { lah }\end{array}$ & $\%$ \\
\hline \multicolumn{4}{|c|}{ Job Insecurity } \\
\hline 1 & $\begin{array}{l}\text { Pekerjaan tidak penting } \\
\text { dan membosankan }\end{array}$ & 3 & 25 \\
\hline 2 & $\begin{array}{l}\text { Tidak berdaya terhadap } \\
\text { aspek-aspek pekerjaan }\end{array}$ & 9 & 75 \\
\hline 3 & $\begin{array}{l}\text { Tidak berdaya terhadap } \\
\text { peristiwa-peristiwa yang } \\
\text { mempengaruhi pekerjaan }\end{array}$ & 6 & 50 \\
\hline 4 & $\begin{array}{l}\text { Merasa pesimis terhadap } \\
\text { masa depannya }\end{array}$ & 7 & 58 \\
\hline 5 & $\begin{array}{ll}\text { Merasa tidak aman } & 1-2 \\
\text { tahun mendatang }\end{array}$ & 5 & 41 \\
\hline \multicolumn{4}{|c|}{ Turnover Intention } \\
\hline 1 & $\begin{array}{l}\text { Mempertimbangkan keluar } \\
\text { dari organisasi }\end{array}$ & 9 & 75 \\
\hline 2 & $\begin{array}{l}\text { Mencari kesempatan untuk } \\
\text { mendapatkan pekerjaan di } \\
\text { organisasi lain }\end{array}$ & 9 & 75 \\
\hline 3 & $\begin{array}{lll}\begin{array}{l}\text { Berfikir berhenti } \\
\text { pekerjaan }\end{array} & \text { dari } \\
\end{array}$ & 7 & 58 \\
\hline 4 & $\begin{array}{l}\text { Aktif mencari pekerjaan } \\
\text { baru }\end{array}$ & 7 & 58 \\
\hline
\end{tabular}

Sumber: PT Sandy Globalindo (2016)

Berdasarkan Tabel 1, dapat dilihat bahwa tiap tahunnya jumlah karyawan yang keluar mengalami kenaikan dan berbanding terbalik dengan karyawan masuk. Berdasarkan hasil wawancara dengan bapak Rizza Miftah (27/3) selaku manajer produksi 1 (PT Sandy Globalindo, terdapat beberapa alasan karyawan keluar dari perusahaan, seperti sakit/meninggal dunia, mendapatkan tawaran gaji dan tunjangan yang lebih baik dari perusahaan lain, dan kepentingan pribadi lainnya. Wawancara juga dilakukan kepada 12 orang karyawan untuk mengetahui bagaimana job insecurity dan turnover intention yang dirasakan. Berikut hasil wawancara disajikan dalam tabel 2 .

Tabel 2 Wawancara Pra-Penelitian

\begin{tabular}{|c|c|c|c|c|}
\hline Thn & $\begin{array}{c}\text { Jumlah } \\
\text { Kary. } \\
\text { Awal } \\
\text { Tahun }\end{array}$ & $\begin{array}{c}\% \\
\text { Kary. } \\
\text { Masuk }\end{array}$ & $\begin{array}{c}\text { \% } \\
\text { Kary. } \\
\text { Keluar }\end{array}$ & $\begin{array}{c}\text { Jumlah } \\
\text { Kary. } \\
\text { Akhir } \\
\text { Tahun }\end{array}$ \\
\hline 2011 & 64 & $20,5 \%$ & $2,6 \%$ & 78 \\
\hline 2012 & 78 & $41,7 \%$ & $6,7 \%$ & 120 \\
\hline 2013 & 120 & $35,3 \%$ & $7,2 \%$ & 167 \\
\hline 2014 & 167 & $5,3 \%$ & $15,1 \%$ & 152 \\
\hline 2015 & 152 & $0 \%$ & $38,2 \%$ & 110 \\
\hline
\end{tabular}

Sumber: Data olahan penulis (2016)

\section{Perumusan Masalah}

Berdasarkan latar belakang di atas, maka dirumuskan masalah yang akan diteliti yaitu:

1. Bagaimana gambaran mengenai job insecurity di PT Sandy Globlindo.

2. Bagaimana gambaran mengenai turnover intention di PT Sandy Globalindo.

3. Bagaimana pengaruh job insecurity terhadap turnover intention pada karyawan PT Sandy Globalindo.

\section{Tujuan Penelitian}

Dari rumusan masalah di atas, tujuan penelitian ini dilakukan untuk mengetahui:

1. Job insecurity di PT Sandy Globalindo.

2. Turnover intention di PT Sandy Globalindo.

3. Pengaruh job insecurity terhadap turnover intention di PT Sandy Globalindo. 


\section{Hipotesis}

Berdasarkan fenomena yang dipaparkan pada latar belakang, maka hipotesis untuk penelitian ini adalah sebagai berikut:

H0: Tidak ada pengaruh yang signifikan antara job insecurity terhadap turnover intention di PT Sandy Globalindo.

Ha: Ada pengaruh yang signifikan antara job insecurity terhadap turnover intention di PT Sandy Globalindo.

\section{KAJIAN LITERATUR Job Insecurity}

Greenhalgh \& Rosenblatt dalam Sora et al. (2010: 59), mendefinisikan job insecurity adalah perasaan ketidakberdayaan untuk mempertahankan kelanjutan pekerjaan karena ancaman situasi dari pekerjaan. Sedangkan Rony \& Bram dalam Sanny \& Kristanti (2012: 63) mendefinisikan ketidakamanan pekerjaan adalah kondisi di mana karyawan merasa terancam oleh ketidakpastian keberlanjutan dalam bekerja di organisasi mereka. Penampilan ketidakamanan kerja akan menimbulkan dampak negatif terhadap fisik dan psikologis karyawan baik dalam jangka pendek dan jangka panjang. Lewis dalam Andrinirina dkk. (2015: 2) mengartikan ketidakamanan kerja sebagai kondisi psikologis seseorang (karyawan) yang menunjukan rasa bingung atau merasa tidak aman dikarenakan kondisi lingkungan yang berubah-ubah (perceived impermanence).

Ada beberapa faktor yang mempengaruhi job insecurity. Menurut Suhartono dalam Wardani dkk. (2014: 3) ada beberapa hal yang menjadi masalah dalam job insecurity diantaranya sebagai berikut:

1. Kondisi pekerjaan adalah segala sesuatu yang ada di sekitar individu yang dimaksud, baik itu berinteraksi langsung maupun tidak langsung dengan pekerja yang bersangkutan. Hal ini meliputi lingkungan kerja beban kerja (kuantitatif dan kualitatif), dan pekerjaan berisiko tinggi
2. Konflik peran. Masalah lain yang timbul adalah ketidakjelasan peran dalam bekerja sehingga tidak tahu apa yang diharapkan manajemen dari diri karyawan tersebut.

3. Pengembangan karir. Ketidakjelasan jenjang karir, penilaian prestasi kerja, seringkali menimbulkan suatu kecemasan terhadap keberlangsungan pekerjaan, rasa bosan, dan dismotivasi sehingga karyawan tidak produktif lagi.

Ashford dkk. (dalam Kuding \& Kurnia, 2011: 69) telah mengkategorikan penyebab job insecurity ke dalam tiga kelompok sebagai berikut:

1. Kondisi lingkungan dan organisasi. Faktor yang mempengaruhi seperti komunikasi dan perubahan organisasional.

2. Karakteristik individual dan jabatan pekerja. Faktor yang mempengaruhi yaitu usia, gender, senioritas, pendidikan, posisi pada perusahaan, latar belakang budaya, status ekonomi sosial, dan pengalaman kerja.

3. Karakterisktik personal pekerja. Faktor yang mempengaruhi yaitu locus of control dan perasaan optimis atau pesimis pada karyawan.

Menurut Modrek \& Cullen (2013: 2) job insecurity berdampak pada timbulnya stress kerja yang memiliki efek merugikan pada kesehatan. Wageenar et al. (2012: 764), berpendapat bahwa job insecurity memiliki dampak terhadap kesehatan seperti stress kerja dan berdampak pula terhadap kesejahteraan karyawan, karena pekerjaan merupakan pusat kehidupan banyak orang karena memenuhi kebutuhan sebagai pendapatan dan kontak sosial.

Menurut Ashford dkk. (dalam Kuding \& Kurnia, 2011: 69) diketahui bahwa job insecurity yang tinggi akan dirasakan karyawan berhubungan dengan:

1. Keinginan untuk mencari pekerjaan baru,

2. Komitmen organisasi yang rendah,

3. Kepercayaan organisasi rendah, dan

4. Kepuasan kerja yang rendah. 


\section{Turnover Intention}

Firth (dalam Oetomo, 2012: 153) mendefinisikan turnover intention adalah kecenderungan atau niat karyawan untuk berhenti dari pekerjaannya secara sukarela menurut pilihannya sendiri. Sedangkan Mobley (dalam Melky, 2015: 698) menambahkan bahwa turnover intention adalah penghentian keanggotaan dalam organisasi oleh individu yang berkeinginan untuk pindah kerja dengan menerima upah moneter organisasi

Turnover intention berkurang ketika karyawan memiliki motivasi intrinsik tinggi, misalnya pengembangan karir dan motivasi ektrinsik, misalnya gaji. (Houskes et al., dalam Kim, 2015: 499). Sedangkan turnover intention lebih tinggi di antara karyawan yang merasa kurang berhubungan dengan rekan kerja mereka, tidak merasa terhubung dengan pekerjaan mereka, dan mengorbankan untuk meninggalkan organisasi mereka saat ini (Sablynski \& Erez, dalam Kim, 2015: 500).

Menurut Ertas (2015: 407), tingkat turnover yang tinggi biasanya menunjukkan bahwa karyawan tidak puas dengan posisi mereka atau organisasi mereka, namun ketidakpuasan ini dapat disebabkan oleh beberapa faktor, misalnya merasa kurang dalam menerima gaji, merasa tidak dihargai, atau pekerjaan tidak cukup menantang. Sedangkan menurut Steele et al., (2012: 626) niat pengunduran diri dipengaruhi oleh keterlibatan kerja, dukungan organisasi, dan semangat.

Menurut Al Malki et al. (2012: 3), faktor turnover meliputi jenis kelamin, usia, status perkawinan, anak-anak, orang dewasa, kebangsaan, etnis, tingkat pendidikan, masa menyusui, masa organisasi, dan penguasaan posisi. Ada banyak faktor lain yang membuat individu memiliki keinginan untuk berpindah. Menurut Handoyo (dalam Yanita, 2012: 2), faktor-faktor tersebut diantaranya adalah lingkungan kerja, komitmen organisasi dari karyawan, kepercayaan terhadap organisasi, dan job insecurity.
Faktor-faktor yang menyebabkan turnover intention menurut Sun et al., (2013: 1060) adalah paket gaji, rendahnya kesempatan belajar dan pelatihan, kurangnya promosi dan ruang pengembangan individu, hubungan interpersonal, stres kerja, pengaruh sibuk bekerja, kondisi kerja, keluarga lingkungan hidup, perwujudan nilai individu, dan suasana penelitian ilmiah.

Konsekuensi yang dihadapi oleh organisasi dalam turnover karyawan dapat dibagi menjadi dua aspek yang terdiri biaya langsung dan biaya tidak langsung. Menurut Wood \& Macaulay (dalam Ramli et al., 2014: 323), biaya langsung adalah konsumsi organisasi waktu dan uang dalam menemukan, mempekerjakan dan melatih karyawan baru. Sedangkan untuk biaya tidak langsung, hal itu terjadi selama proses pencarian karyawan baru bahwa organisasi mengalami penurunan produktivitas terutama dalam pelayanan disebabkan oleh understaffing dan juga dengan pengalaman dari karyawan baru. Biaya turnover rata-rata untuk karyawan profesional penuh waktu di sektor swasta telah diperkirakan setinggi $150 \%$ dari paket kompensasi tahunan karyawan (Schlesinger \& Heskett dalam Pitts et al., 2011:751).

Abston \& Kupritz (2012: 12) berpendapat bahwa biaya nyata yang disebabkan oleh turnover antara lain pengolahan dokumen pemisahan, merekrut, memilih dan melatih karyawan pengganti, kehilangan produktivitas. Sedangkan biaya tidak berwujud yang sulit untuk mengukur tetapi juga dapat merusak organisasi termasuk moral rendah, layanan buruk terhadap pelanggan, dan ketidakpuasan pelanggan.

\section{METODE}

Objek penelitian ini mengenai perilaku organisasi yang difokuskan pada job insecurity, turnover intention dan ditujukan kepada seluruh karyawan PT Sandy Globalindo yang berjumlah 135 orang terdiri dari delapan departemen. 


\begin{tabular}{|c|c|}
\hline Job Insecurity & Turnover Intention \\
\hline $\begin{array}{l}\text { 1. Severity of threat } \\
\text { 2. Powerlessness } \\
\text { (Greenhalgh \& Rosenblatt } \\
\text { dalam Kuding \& Kurnia, } \\
\text { 2011: 69) }\end{array}$ & $\begin{array}{l}\text { 1. Niat untuk berhenti dari } \\
\text { pekerjaan } \\
\text { 2. Niat untuk meninggalkan } \\
\text { organisasi } \\
\text { (Paille \& Grimm (2011: 483)) }\end{array}$ \\
\hline
\end{tabular}

\section{Gambar 2. Paradigma Peneltian}

Penelitian yang dilakukan adalah penelitian eksplanatori, yaitu penelitian yang menjelaskan hubgann kedua variabel dengan menjelaskan suatu fenomena tertentu. Sedangkan metode penlitian yang digunakan adalah metode penelitian deskriptif, yaitu metode penelitian untuk menggambarkan fenomena yang ada berdasarkan data yang ada dengan tujuan untuk menguji hipotesis yang telah ditetapkan.

Dalam penelitian ini, yang menjadi variabel bebas adalah job insecurity dan variabel terikatnya adalah turnover intention. Variabel bebas diukur dengan menggunakan dimensi dari Greenhalgh \& Rosenblatt sedangkan variabel bebas diukur menggunakan dimensi dari Paille Grim dengan menggunakan 5 skala likert.

Populasi penelitian sebanyak 135 karyawan dan sampelnya adalah 101 hasil dari formula Slovin. Data yang digunakan adalah data primer byang berasal dari hasil wawancara dan kuesioner. Data sekunder digunakan sebagai pengetahuan dalam menjawab masalah penelitian yang didapat dari buku dan jurnal.

Sebelum kuesiner disebar ke seluruh sampel, kuesioner diji teerlebih dahulu validitas dan reliabilitasnya. Menurut Arikunto (2010: 211) validitas adalah suatu ukuran yang menunjukkan tingkat-tingkat kevalidan atau kesahihan suatu instrument. Semua instrument dalam kuesioner valid karena nilai corrected item correlation lebih tingi dibanding 0,196. Menurut Arikunto (2010: 221) reliabilitas menunjukkan bahwa suatu instrumen cukup dapat dipercaya untuk digunakan seebagai alat pengumpul data karena instrument tersebut sudah baik. Semua instrumen dalam kuesioner baik karena nlai croncbanch alpha's lebih tinggi dibanding 0,6. Setelah semua instrumen dalam kuesoner valid dan baik (reliable), data kemudian diji secara statistik menggunakan uji deskriptf, korelasi, regresi, koefisien determinasi, dan hipotesis.

\section{HASIL DAN PEMBAHASAN Identitas Responden}

Tabel 3 menunjukkan identitas responden dalam penelitian ini.

Tabel 3. Identitas Responden

\begin{tabular}{|c|c|c|c|}
\hline Identitas & Keterangan & $\begin{array}{c}\text { Res- } \\
\text { ponden }\end{array}$ & $\%$ \\
\hline \multirow{2}{*}{$\begin{array}{l}\text { Jenis } \\
\text { Kelamin }\end{array}$} & Pria & 93 & 92,1 \\
\hline & Wanita & 8 & 7,9 \\
\hline \multirow{4}{*}{$\begin{array}{l}\text { Lama } \\
\text { Bekerja }\end{array}$} & $<1$ tahun & 6 & 5,9 \\
\hline & $1-2$ tahun & 15 & 14,9 \\
\hline & 3-4 tahun & 42 & 41,6 \\
\hline & $>5$ tahun & 38 & 37,6 \\
\hline \multirow{5}{*}{$\begin{array}{l}\text { Pendidikan } \\
\text { Terakhir }\end{array}$} & SD/Sederajat & 14 & 13,9 \\
\hline & SMP/Sederajat & 24 & 23,8 \\
\hline & SMA/Sederajat & 50 & 49,5 \\
\hline & D1/D2/D3 & 8 & 7,9 \\
\hline & $\mathrm{D} 4 / \mathrm{S} 1$ & 5 & 5 \\
\hline \multirow[t]{4}{*}{ Usia } & $<20$ tahun & 6 & 5,9 \\
\hline & 21-25 tahun & 49 & 48,5 \\
\hline & 26-30 tahun & 33 & 32,7 \\
\hline & $>30$ tahun & 13 & 12,9 \\
\hline
\end{tabular}

Sumber: Data olahan penulis (2016) 


\section{Analisis Deskriptif \\ Job Insecurity}

Berdasarkan Tabel 4 variabel job insecurity memiliki rata-rata jawaban responden paling rendah adalah dua dan jawaban responden paling tinggi adalah empat. Nilai mean variabel job insecurity menunjukkan angka sebesar 3,33 yang berada pada skala interval 2,61 - 3,40 dan termasuk kategori cukup tinggi. Standar deviasi variabel job insecurity menunjukkan angka 0,451 atau sama dengan $13,54 \%$ dari nilai mean, artinya standar deviasi variabel job insecurity tidak lebih dari $20 \%$ dan hal ini menunjukkan bahwa variasi jawaban kecil atau sebagian responden menjawab pernyataan dalam variabel ini dengan jawaban yang relatif sama. Dari kedua dimensi job insecurity, dimensi keparahan ancaman berkontribusi 3,40 dan dimensi ketidakberdayaan berkontribusi 3,26. Berikut pemaparan dari kedua dimensi tersebut.

Tabel 4 Analisis Deskriptif Job Insecurity

\begin{tabular}{|l|r|r|r|r|r|}
\hline & N & Min & Max & Mean & $\begin{array}{l}\text { Std. } \\
\text { Dev }\end{array}$ \\
\hline $\begin{array}{l}\text { Keparahan } \\
\text { Ancaman }\end{array}$ & 101 & 2 & 5 & 3.40 & .452 \\
\hline $\begin{array}{l}\text { Ketidak- } \\
\text { berdayaan }\end{array}$ & 101 & 2 & 5 & 3.26 & .561 \\
\hline $\begin{array}{l}\text { Job } \\
\text { Insecurity }\end{array}$ & $\mathbf{1 0 1}$ & $\mathbf{2}$ & $\mathbf{4}$ & $\mathbf{3 . 3 3}$ & $\mathbf{. 4 5 1}$ \\
\hline
\end{tabular}

\section{Turnover intention}

Berdasarkan Tabel 5 variabel turnover intention memiliki rata-rata jawaban responden paling rendah adalah dua dan jawaban responden paling tinggi adalah empat. Nilai mean variabel turnover intention menunjukkan angka sebesar 3,50 yang berada pada skala interval 3,41 - 4,20 dan termasuk kategori tinggi. Standar deviasi variabel turnover intention menunjukkan angka 0,373 atau sama dengan $10,66 \%$ dari nilai mean, artinya standar deviasi variabel turnover intention tidak lebih dari $20 \%$ dan hal ini menunjukkan bahwa variasi jawaban kecil atau sebagian responden menjawab pernyataan dalam variabel ini dengan jawaban yang relatif sama. Dari kedua dimensi turnover intention ini, dimensi niat untuk berhenti dari pekerjaan saat ini berkontribusi 3,33 dan dimensi niat untuk meninggalkan organisasi berkontribusi 3,65. Berikut pemaparan dari kedua dimensi tersebut.

Tabel 5 Analisis Deskriptif Turnover Intention

\begin{tabular}{|l|r|r|r|r|r|}
\hline & N & Min & Max & Mean & $\begin{array}{r}\text { Std. } \\
\text { Dev }\end{array}$ \\
\hline $\begin{array}{l}\text { Niat untuk } \\
\text { berhenti dari } \\
\text { pekerjaan } \\
\text { saat ini }\end{array}$ & 101 & 2 & 4 & 3.33 & .288 \\
\hline $\begin{array}{l}\text { Turnover } \\
\text { intention }\end{array}$ & $\mathbf{1 0 1}$ & $\mathbf{2}$ & $\mathbf{4}$ & $\mathbf{3 . 5 0}$ & $\mathbf{. 3 7 3}$ \\
\hline
\end{tabular}

\section{Analisis Korelasi}

Berdasarkan Tabel 6 dapat dilihat bahwa korelasi kedua variabel sebesar 0,464. Mengacu terhadap interpretasi nilai korelasi menurut Sugiyono (2013: 25) nilai korelasi 0,464 berada pada skala $0,40-0,599$ yang berarti korelasi antar kedua variabel sedang.

Tabel 6 Korelasi

\begin{tabular}{|l|l|r|r|}
\hline \multicolumn{2}{|c|}{} & \multicolumn{1}{c|}{ JI } & \multicolumn{1}{c|}{ TI } \\
\hline \multirow{3}{*}{$\begin{array}{l}\text { Job } \\
\text { Insecurity }\end{array}$} & $\begin{array}{l}\text { Pearson } \\
\text { Correlation }\end{array}$ & 1 & $.464^{* *}$ \\
\cline { 2 - 4 } & Sig. (2-tailed) & & .000 \\
\cline { 2 - 4 } & $\mathrm{N}$ & 101 & 101 \\
\hline \multirow{3}{*}{$\begin{array}{l}\text { Turnover } \\
\text { intention }\end{array}$} & $\begin{array}{l}\text { Pearson } \\
\text { Correlation }\end{array}$ & $.464^{* *}$ & 1 \\
\cline { 2 - 4 } & Sig. (2-tailed) & .000 & \\
\cline { 2 - 4 } & $\mathrm{N}$ & 101 & 101 \\
\hline
\end{tabular}

**. Correlation is significant at the 0.01 level (2-tailed).

\section{Analisis Regresi}

Berdasarkan Tabel 7 diperoleh konstanta sebesar 26,543 dan koefisien regresi sebesar 0,398. Jika dimasukan ke dalam rumus persamaan regresi maka diperoleh hasil sebagai berikut: $\mathrm{Y}=26,543+0,398 \mathrm{X}$. Tanda positif $(+)$ pada koefisien regresi (b) memiliki arti jika terjadi 
penambahan satu pada $X$, maka mampu meningkatkan Y sebesar 0,398. Jika variabel job insecurity ditingkatkan maka variabel turnover intention meningkat juga, dan sebaliknya jika variabel job insecurity menurun maka variabel turnover intention akan menurun juga.

Tabel 7 Analisis Regresi

\begin{tabular}{|c|c|c|c|c|c|c|}
\hline \multirow{2}{*}{\multicolumn{2}{|c|}{ Model }} & \multicolumn{2}{|c|}{$\begin{array}{l}\text { Unstand. } \\
\text { Coefficients }\end{array}$} & \multirow{2}{*}{ 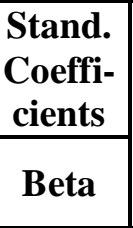 } & \multirow{2}{*}{$\mathbf{t}$} & \multirow{2}{*}{ Sig. } \\
\hline & & B & $\begin{array}{c}\text { Std. } \\
\text { Error }\end{array}$ & & & \\
\hline \multirow{2}{*}{1} & $\begin{array}{l}\text { (Con } \\
\text { stant) }\end{array}$ & 26.543 & 6.285 & & $\begin{array}{r}4.2 \\
23 \\
\end{array}$ & $\begin{array}{r}.00 \\
0\end{array}$ \\
\hline & JI & .398 & .076. & .464 & $\begin{array}{r}5.2 \\
14\end{array}$ & $\begin{array}{r}.00 \\
0\end{array}$ \\
\hline
\end{tabular}

\section{Koefisien Determinasi}

Berdasarkan Tabel 8, nilai $R$ Square pada tabel IV.21 yaitu sebesar 0,215 atau $21,5 \%$. Hal ini berarti job insecurity memiliki pengaruh sebesar $21,5 \%$ terhadap turnover intention, dan 78,5\% dipengaruhi oleh variabel lain yang tidak dimasukan dalam model penelitian ini.

Tabel 8 Koefisien Determinasi

\begin{tabular}{|l|l|r|r|r|}
\hline $\begin{array}{c}\text { Mo- } \\
\text { del }\end{array}$ & R & $\begin{array}{c}\text { R } \\
\text { Square }\end{array}$ & $\begin{array}{c}\text { Adjusted } \\
\text { R Square }\end{array}$ & $\begin{array}{c}\text { Std. } \\
\text { Error of } \\
\text { the Est. }\end{array}$ \\
\hline 1 & $.464^{\mathrm{a}}$ & .215 & .208 & 7.217 \\
\hline
\end{tabular}

Tabel 9 Uji Statistik F

\begin{tabular}{|c|l|r|c|c|}
\hline \multicolumn{2}{|l|}{ Model } & \multicolumn{1}{c|}{ df } & \multicolumn{1}{c|}{ F } & Sig. \\
\hline \multirow{3}{*}{1} & Regression & 1 & 27.186 & $.000^{\mathrm{b}}$ \\
\cline { 2 - 5 } & Residual & 99 & & \\
\cline { 2 - 5 } & Total & 100 & & \\
\hline
\end{tabular}

\section{Uji Hipotesis}

Uji F

Berdasarkan Tabel 9 diperoleh nilai Fo sebesar 27,189 dengan sig. 0,000. Sedangkan untuk $\mathrm{Ft}=(101-2)=99$ maka diperoleh Ftsebesar 3,94. Mengacu kepada interpretasi pengambilan keputusan menurut Arikunto (2010: 368), maka 27,189 $\geq 3,94$ dengan $0,000<0,05$ dan dapat disimpulkan bahwa job insecurity berpengaruh signifikan terhadap turnover intention di PT. PT. Sandy Globalindo.

\section{Uji t}

Tabel 10 Uji Statistik t

\begin{tabular}{|l|l|r|r|}
\hline \multicolumn{2}{|c|}{ Model } & t & \multicolumn{1}{c|}{ Sig. } \\
\hline \multirow{2}{*}{1} & (Constant) & 4.223 & .000 \\
\cline { 2 - 4 } & JI & 5.214 & .000 \\
\hline
\end{tabular}

Berdasarkan Tabel 10 diperoleh nilai thitung sebesar 5,214 dengan sig. 0,000. Sedangkan untuk ttabel $=(101-2)=$ 99 maka diperoleh Ft sebesar 0,198422. Mengacu kepada interpretasi pengambilan keputusan menurut Arikunto (2010: 368), maka 5,214 $\geq 0,198422$ dengan $0,000<0,05$ dan dapat disimpulkan bahwa job insecurity berpengaruh signifikan terhadap turnover intention di PT. Sandy Globalindo.

\section{KESIMPULAN DAN SARAN \\ Kesimpulan}

Berdasarkan hasil analisis dan pembahasan yang telah dipaparkan, maka dapat ditarik kesimpulan untuk menjawab perumusan masalah seperti berikut ini:

1. Job insecurity di PT Sandy Globalindo tergolong dalam kategori cukup tinggi.

2. Turnover intention di PT Sandy Globalindo tergolong dalam kategori tinggi.

3. Job insecurity mempengaruhi turnover intention sebesar 21,5\%, sedangkan $78,5 \%$ sisanya dipengaruhi hal lain yang tidak dimasukan dalam penelitian ini. Berdasarkan hasil regresi sederhana diperoleh persamaan $\mathrm{Y}=26,543+$ 0,398X. Dengan demikian, jika karyawan PT Sandy Globalindo mengalami peningkatan job insecurity, maka turnover intention karyawan di PT Sandy Globalindo akan meningkat pula.

\section{Saran}

Berdasarkan kesimpulan dan pembahasan yang telah dipaparkan, maka 
adapun saran yang diberikan untuk PT Sandy Globalindo dalam menekan job insecurity dan turnover intention adalah seperti berikut ini:

1. Untuk menekan tingginya job insecurity yang dirasakan oleh karyawan, maka manajemen harus mampu mengatur peran karyawan dengan jelas sesuai deskripsi kerjanya sehingga karyawan tidak merasakan adanya beban kerja yang berat karena harus melakukan berbagai pekerjaan. Selain itu, perusahaan harus memberikan beberapa program pelatihan dan pengembangan yang dapat membantu karyawan untuk mengenali kesempatan kerja yang lebih luas dan kondisi lingkunga yang nyaman didalam organisasi.

2. Perusahaan perlu menekan tingginya tingkat turnover intention dengan beberapa cara seperti: melakukan interview dengan karyawan yang keluar dari perusahaan untuk mengetahui alasan dan tujuan karyawan meninggalkan perusahaan sehingga menjadi informasi yang berguna sebagai masukan dalam menentukan kebijakan perusahaan, perusahaan perlu memperhatikan kenyamanan karyawan dalam bekerja (lingkungan, gaji, kepemimpinan atasan, penempatan karyawan, peningkatan mutu pengawasan secara keseluruhan dll) dalam upaya meningkatkan kepuasan kerja dan mendorong motivasi karyawan

3. Job insecurity mempengaruhi turnover intention sebesar 21,5\%. Turnover intention dipengaruhi oleh keinginan untuk mencari pekerjaan baru di bidang yang sama namun dalam organisasi yang berbeda, keinginan untuk mencari pekerjaan baru di bidang yang berbeda, dan keinginan untuk mencari pekerjaan baru. Oleh karena itu, hal-hal lain seperti paket gaji, rendahnya kesempatan belajar dan pelatihan, kurangnya promosi dan ruang pengembangan individu, hubungan interpersonal, stres kerja, pengaruh sibuk bekerja, kondisi kerja, keluarga lingkungan hidup, perwujudan nilai individu, dan suasana penelitian ilmiah merupakan faktor-faktor lain yang mempengaruhi turnover intention perlu diperhatikan juga.

\section{DAFTAR PUSTAKA}

Abrams, D. E., \& Hogg, M. A. (1990). Social identity theory: Constructive and critical advances. Springer-Verlag Publishing.

Abston, Kristie A. \& Kupritz, Virginia W. (2011). Employees as Customers: Exploring Service Climate, Employee Patronage, and Turnover. Performance Improvement Quarterfly, Vol. 23, No. 4, pp. 7-26.

Almalki, M. J. Fitzgerald, G., \& Clark, M. (2012). "The Relationship BetweenQuality of Work Life and Turnover Intention of Primary Health Care Nurses in Saudi Arabia". BMC Health Services Research 2012, 12:314.

Andrinirina, M., Sudarsih, I. K.M. D. (2015). "Pengaruh Lingkungan Kerja, dan Job Insecurity terhadap Kinerja dan Turnover Intention karyawan pada Royal Hotel n'lounge Jember". Artikel Ilmiah Mahasiwa 2015, hal. 1-7.

Arikunto, S. (2010). Prosedur Penelitian: Suatu Pendekatan Praktik. Edisi Revisi. Jakarta: Rineka Cipta.

Daryanto \& Abdullah. (2013). Pengantar Ilmu Manajemen dan Komunikasi. Jakarta: Prestasi Pustakaraya.

Ertas, N. (2015). Turnover Intentions andWork Motivations of Millennial Employees in Federal Service. SAGE: Public Personnel Management 2015, Vol. 44(4) 496-519.

Hanafiah, M. (2014). Pengaruh Kepuasan Kerja dan Ketidakamanan Kerja (Job Insecurity) dengan Intensi Pindah Kerja (Turnover) pada Karyawan PT Buma Desa Suaran Kecamatan Sambaliung Kabupaten Berau. eJournal Psikologi, 2014, 1 (3): 303-312.

Kadiman, \& Indriana R. D. (2012). Pengaruh Budaya Organisasi, Komitmen Organisasi, dan Kepuasan Kerja Terhadap Turnover Intention Karyawan 
(Studi Kasus pada PT Nyonya Meneer Semarang). Juraksi. 1(1), hal: 57-72.

Kim, J. (2015). What Increases Public Employees' Turnover Intention?. SAGE: Public Personnel Management 2015, Vol. 44(4) 496-519

Kuding, G. M. P., \& Kurnia, R. (2011). Pengaruh Job Insecurity, terhadap Keinginan Berpindah Kerja dengan Kepuasan Kerja dan Komitmen Organisasional sebagai Variabel Intervening (Studi pada Karyawan Pertelevisian di Jakarta). Ultima Accounting, Vol. 3, No. 1, Hal. 66-85.

Melky, Y. (2015). Hubungan kepuasan kerja dan komitmen organisasi terhadap intensi pindah kerja (turnover intention) karyawan PT Rejeki abadi sakti samarinda. eJournal Psikologi Fisip Unmul 2015, 3 (3) : 694-707.

Modrek, S., \& Cullen, M. C. (2013). Job Insecurity During Recessions: Effects on Survivior' Work Stress. BMC Public Health, Vol. 13, pp. 1-11.

Nopiando, B. (2012). Hubungan Antara Job Insecurity Dengan Kesejahteraan Psikologis Pada Karyawan Outsourcing. Journal of Social and Industrial Psychology JSIP 1 (2).

Oetomo, H. W. (2012). Analisis Hubungan Antara Stres Dan Intention To Quit Dengan Kompensasi Sebagai Variabel Intervening. JAMBSP Vol. 8 No. 2 Februari 2012: 147 - 163.

Palille, P., \& Grim, F. (2011). Citizenship and Withdrawal in the Workplace: Relationship Between Organizational Citizenship Behavior, Intention to Leave Current Job and Intention to Leave the Organization. The Journal of Social Psychology, 2011, 151(4), 478-493..

Pitts, D., Marvel, J., \& Fernandez, S. (2011). So Hard to Say Goodbye? Turnover Intention among U.S. Federal Employees. Public Administration Review September-Oktober.

Ramli, A. A. Salahudin, Shahrul Nizam. Zainol, Zaifudin. Suandi, Turiman. (2014). Turnover Intention among
Academics: A Case Study of PrivateHigher Learning Education in Klang Valley. Pertanika J. Soc. Sci. \& Hum. 22 (1): 321 - 334.

Sanny, L., \& Kristanti, S. (2012). Pengaruh Lingkungan Kerja dan Job Insecurity terhadap Motivasi Kerja dan Dampaknya pada Kinerja Karyawan Outsourcing Mall Lippo Cikarang. Binus Business Review, Vol. 3 No. 1, Hal. 61-69.

Sora, B., Caballer, A., \& Peiro, Jose M. (2010). The Consequences of Job Insecurity for Employees: The Moderator Role of Job Depedence. International Labour Review, Vol. 149, No. 1, pp. 5972.

Steele, J. P., Rupayana, D. D., Mills, M. J., Smith, M. R., \& Downey, A. (2012). Relative Importance and Utility of Positive Worker States: A Review and Empirical Examination. The Journal of Psychology, 2012, 146(6), 617-650.

Sun, Y. L. Z., \& Fang, P. (2013). Factors Influencing the Turnover Intention of Chinese Community Health Service Workers Based on the Investigation Results of Five Provinces. Springer Science Business Media New York: $J$ Community Health, Vol. 38, pp. 10581066.

Usman, H. (2010). Manajemen: Teori, Praktik, dan Riset Pendidikan. Jakarta: Bumi Aksara.

Wageenar, A. F., Kompier, M. A. J., Houtman, I. L. D., Bossche, S. V. D., Smulders, P., \& Taris, T. W. (2012). Can labour contract differences in health and work-related attitudes be explained by quality of working life and job insecurity?. International Arch Occup Environ Health, Vol. 85, pp. 763-773.

Wardani, S. I., Sutrisno, \& Pramono, R. E. (2014). Pengaruh Job Insecurity terhadap Turnover Intention Karyawan CV. Putra Makmur Abadi Temanggung Jawa Tengah. Artikel Ilmiah Hasil Penelitian Mahasiswa, Hal. 1-7.

Waspodo, A. A. W. S. (2013). Pengaruh Kepuasan Kerja dan Stress Kerja 
Terhadap Turnover Intention Pada Karyawan PT Unitex di Bogor. Jurnal Riset Manajemen Sains Indonesia (JRMSI) Vol 4 No.1 2013 h97-115.

Yunita, P. (2012). Pengaruh Kompensasi, Komitmen Organisasi, dan Job Insecurity Terhadap Intention to Turnover Pada Dosen Sekolah Tinggi Ilmu Ekonomi Sakti Alam Kerinci. 